УДК 378.146

Дибкова Людмила Миколаївна

кандидат педагогічних наук, доцент кафедри інформатики

Державний вищий навчальний заклад «Київський національний економічний університет

імені Вадима Гетьмана», м. Київ, Україна

dybln@meta.ua

\title{
ІНФОРМАЦІЙНО-КОМУНІКАЦІЙНІ ТЕХНОЛОГІЇ У КОНТЕКСТІ ОЦІНЮВАННЯ РЕЗУЛЬТАТІВ НАВЧАННЯ СТУДЕНТІВ ВНЗ УКРАЇНИ
}

\begin{abstract}
Анотація. Стаття присвячена оцінюванню результатів навчальної діяльності студентів із використанням сучасних інформаційно-комунікаційних технологій. Автор підкреслює, що метою сучасної системи освіти $є$ не тільки набуття майбутніми фахівцями професійних знань $\mathrm{i}$ навичок, а й формування здатності до постійного їх оновлення та модернізації у майбутній професійній діяльності. Важливим $€$ здійснення студентами оцінювання отриманих результатів через максимальну інформованість про критерії оцінювання знань та вмінь 3 кожної дисципліни, а також доступність навчальних результатів через електронний журнал, який розміщений у мережі Інтернет. У статті проаналізовано навчальні завдання, які засновані на активному використанні можливостей інформаційно-комунікаційних технологій у процесі проведення лекцій, практичних занять, самостійної роботи і тестування.
\end{abstract}

Ключові слова: активна оцінна діяльність студентів; інформаційно-комунікаційні технології; навчальне завдання; оцінювання навчальних результатів; самостійна робота студентів.

\section{1. ВСТУП}

Постановка проблеми. Рівень професійної компетентності майбутніх фахівців все більше залежить від їх здатності самостійно аналізувати свій освітній рівень, виявляти недоліки, набувати нові знання, вміння та навички, що дозволить в майбутньому швидко адаптувати свої знання до сучасних технологій, які постійно розвиваються та вдосконалюються. Лише свідоме і критичне відношення студентів до власних навчальних результатів, розуміння цілей свого професійного розвитку, аналітичний підхід до процесу навчання, чітке проектування своєї індивідуальної освітньої траєкторії збільшить результативність освітньої діяльності.

Глобальна інформатизація всіх суспільних процесів, постійне зростання обсягу інформаційних професійно-орієнтованих масивів, стрімкий розвиток технологій спонукають до реформування освітньої парадигми через активізацію навчальної діяльності студентів, реалізацію суб'єкт-суб'єктних відносин між викладачем і студентом, збільшення частки самостійної роботи, що виконується студентами. За таких умов застосування широких можливостей інформаційно-комунікаційних технологій стає невід'ємною компонентою навчального процесу.

Аналіз останніх досліджень і публікацій. Питання впровадження інформаційних технологій у навчальний процес вищої школи $\epsilon$ актуальним у сучасних наукових дослідженнях, зокрема, у працях таких авторів, як В. Безпалько, І. Булах, М. Жалдак, О. Матвієнко (застосування інформаційних технологій у професійній освіті), В. Биков, Ю. Жук, В. Кухаренко (системи відкритої освіти), Р. Гуревич, Н. Морзе, С. Полат, Т. Поясок (психолого-педагогічні засади впровадження інформаційних технологій в 
навчальний процес вищої школи) та багатьох інших.

Мета статті. Проте, незважаючи на широкий спектр питань, які розглядаються, недостатньо дослідженими залишаються певні аспекти використання інформаційнокомунікативних технологій оцінювання та самооцінювання навчальних результатів як засобу оцінювання та самооцінювання навчальних результатів, активізації навчальнопізнавальної діяльності студентів та розвитку їх творчого мислення, а також як метод осучаснення навчально-методичного забезпечення дисципліни.

\section{2. МЕТОДИ ДОСЛІДЖЕННЯ}

Методологічну основу дослідження складають базові принципи розвитку педагогіки і психології в умовах інформаційного суспільства. Для досягнення поставленої мети використовувалися методи: а) теоретичні: аналіз науково-педагогічної та методичної літератури 3 проблеми дослідження - застосування інформаційно-комунікаційних технологій у процесі оцінювання навчальних результатів студентів ВН3; б) емпіричні: аналіз активності студентів у процесі оцінювання навчальних результатів при проведенні лекцій, практичних занять, тестування; спостереження; систематизація й узагальнення власного досвіду й досвіду колег-викладачів ДВНЗ «Київський національний економічний університет імені Вадима Гетьмана».

\section{3. РЕЗУЛЬТАТИ ДОСЛІДЖЕННЯ}

Пріоритетним завданням сучасної освіти стає формування у студентів мотивації на вироблення власної активної освітньої стратегії, яка дозволяє ставити власні цілі, створювати індивідуальну траєкторію їх досягнення, самостійно обирати освітні засоби їх здійснення. Саме широка участь студентів у освітньому процесі як повноправного суб'єкта збільшує їх відповідальність за ефективність навчання та зумовлює внесення суттєвих змін у політику проведення оцінювання навчальних результатів.

У сучасних умовах загальної інформатизації застосування інформаційнокомунікаційних технологій в освітній діяльності здійснюється при викладанні більшості навчальних дисциплін, і для студентів сучасних вишів володіння навичками роботи 3 програмними продуктами $\epsilon$ загальноприйнятими. На початку 2016 р. ми провели дослідження серед студентів-першокурсників Київського національного економічного університету імені Вадима Гетьмана (105 респондентів). Було поставлено питання: «Якими соціальними мережами та програмами-месенджерами Ви користуєтесь?». Результати, представлені на рисунку 1, свідчать про $100 \%$ володіння студентами навичками роботи із певними програмними продуктами.

Ми порівняли результати проведеного нами дослідження із тими, які ще у 2010 p. було опубліковано Т. Поясок. Зокрема, автор зазначила: «Вивчення сучасного стану застосування інформаційних технологій у професійній підготовці майбутніх фахівців економічного профілю у вищих навчальних закладах показало, що серед 980 опитаних студентів, які навчаються за спеціальностями галузі знань «Економіка та підприємництво», тільки 66,9\% вміють працювати з комп'ютером; 44,1\% мають постійний доступ до ПК; 26,8\% уміють самостійно працювати в мережі Інтернет» [3, с.21].

Таким чином, аналіз результатів двох досліджень дає змогу зробити висновок про 
швидкі темпи розвитку інформаційної компетентності молоді у нашій країні, що спонукає викладачів до більш активного використання у навчальній діяльності можливостей інформаційно-комунікаційних технологій, реалізації диференційованого підходу до студентів, доповнення існуючого навчально-методичного забезпечення навчальних дисциплін. Це обумовлює збільшення мотивації студентів до успішного навчання, дає змогу їм розвивати особистісні якості, впливає на вибір методів і способів діяльності та мислення.



Рис. 1. Результати дослідження серед студентів-першокурсників

Проаналізуємо означені аспекти застосування інформаційно-комунікаційних технологій у контексті оцінювання результатів навчальної діяльності студентів.

Активізація навчальної діяльності студентів призводить до зміни і функцій сучасної лекції, яка все більше орієнтується на стимулювання студентів на подальшу самостійну роботу. «Завдання сучасного лектора - не стільки надати інформацію, скільки спонукати студентів до самостійного вивчення теми, формування власного ставлення до певних іiі аспектів, пошуку джерел додаткової інформації, стимулювання студентів до подальшої самостійної роботи. У цьому разі не самостійна робота має стати складовою лекції, а лекція - складовою самостійної роботи. У такому розумінні навчальну діяльність студентів на лекції можна вважати самостійної роботою, що має бути проконтрольована та оцінена викладачем» [2, с. 174].

Проведення лекцій у багаточисельних аудиторіях студентів має такі недоліки, як складнощі оцінювання рівня розуміння кожним студентом навчального матеріалу, який розглядається; недостатня чіткість візуального відображення інформації викладачем (на дошці, слайдах тощо), певні утруднення при спробах дискусійного обговорення того чи іншого питання. Використання інформаційно-комунікативних технологій при проведенні 
лекцій створює можливості для активної та творчої участі студентів та усунення зазначених недоліків. Лекція проводиться із використанням комплексу технічних засобів (ноутбук, проектор), обсяг навчального матеріалу, який розглядається, представлений стисло у надрукованому вигляді (при вивченні інформатики - це і вбудовані копії екрану монітору, термінологія, алгоритми виконання дій тощо). Студенти протягом лекційного заняття пишуть не конспект цілої теми, а лише деякі доповнення чи нотатки, а також беруть активну участь у лекції через вирішення навчальних задач, обговорення навчальних ситуацій.

Таким чином, інформаційно-комунікативні технології при проведенні лекцій надають викладачу такі додаткові можливості:

- через розроблені презентації унаочнювати, структурувати навчальний матеріал; представляти окремі елементи у збільшеному вигляді;

- демонструвати студентам вирішення навчальних задач за допомогою програмного продукту;

- оцінювати рівень розуміння аудиторією навчального матеріалу, який розглядається. Для цього після пояснення певного інформаційного блоку, ми пропонуємо студентам невеликі за обсягом завдання для знаходження ними певного рішення. Після незначного відрізку часу, протягом якого ми можемо спостерігати за роботою кожного студента, демонструється слайд із еталоном рішення. Студенти самостійно порівнюють отримані результати із тими, які виводяться на екрані, та виправляють свої помилки;

- за результатами постійного оцінювання рівня розуміння студентами навчального матеріалу, який розглядається, можна вносити певні корективи у процес проведення лекції: повернутися ще раз до складних питань або скоротити їх пояснення у випадку розуміння їх студентами.

Такий підхід створює для викладача можливість контролювати діяльність кожного студента та заохочувати їх до активної навчальної діяльності. Навчальні матеріали напередодні проведення лекції ми розміщуємо у мережі Інтернет, що дає змогу студентам попередньо ознайомитися та, за необхідності, роздрукувати навчальний матеріал, який буде розглядатися, що збільшує продуктивність лекції. Водночас всі матеріали лекцій доступні протягом періоду вивчення навчальної дисципліни кожному студенту, незалежно від присутності на лекції. Також створюється можливість для швидкого осучаснення навчально-методичного забезпечення навчальних дисциплін, доповнення існуючих підручників та навчальних посібників.

При проведенні практичних занять застосування інформаційно-комунікаційних технологій дає змогу використовувати навчальні завдання, розроблені на принципах інтерактивності, проблемності, самооцінювання, що має суттєвий вплив на розвиток професійних та особистісних якостей майбутніх фахівців. У таких завданнях представлений кінцевий вигляд роботи, тому студенти мають виконати аналітичну діяльність: виявити ті чи інші навчальні блоки у завданні, відібрати та використати відповідний інструментарій для знаходження правильної відповіді, тобто «реконструювати» попередньо заданий кінцевий результат. При цьому засвоєння знань та набуття навиків здійснюється через активну самостійну діяльність студентів, відбувається розвиток їх особистісних якостей (відповідальність, ініціативність), формується адекватна самооцінка, посилюється мотивація до досягнення поставлених цілей.

Викладач при цьому має можливість спостерігати за роботою кожного студента, надавати консультацію та допомогу, скеровувати його до знаходження правильної 
відповіді. На відміну від традиційної форми проведення практичних занять, коли студент не мотивований на самостійне вирішення проблем та втрачає інтерес, очікуючи вказівок викладача щодо знаходження та виправлення помилок при вирішенні навчальної задачі, запропоновані нами навчальні завдання вміщують елементи самоконтролю, і студенти можуть самостійно оцінити, чи правильно вони вирішити поставлену задачу [3].

Необхідно зазначити, що проведене нами дослідження виявило високу ефективність виконання студентами завдань для самостійного опрацювання після прослуховування лекції напередодні практичного заняття. Це стимулює студентів до ретельного опрацювання навчального матеріалу перед проведенням заняття та створює можливості викладачу для більш ефективного проведення навчального заняття, спрямовуючи зусилля на ту частину навчального матеріалу, яку студенти не змогли виконати самостійно. Такі завдання ми також розміщуємо у мережі Інтернет, і вони доступні протягом періоду вивчення дисципліни.

Додаткові дидактичні можливості при проведенні контрольних заходів надають тестові технології, реалізовані через програмні продукти. У Київському національному економічному університеті імені Вадима Гетьмана запроваджена система дистанційного навчання Moodle. Ця програма має чудові можливості для розробки викладачем тестових завдань та використання їх у навчальному процесі. Миттєвий зворотній зв'язок значно підвищує мотивацію до навчання у студентів через можливість переглянути отримані результати та проаналізувати помилки, надає гнучкі та зручні інструменти для викладача у процесі розробки тестових завдань. Розглянемо їх більш детально.

Спочатку відповідно до попередньо визначених результатів навчання, створюється база тестових завдань різних типів з окремого тематичного блоку навчальної дисципліни. У системі дистанційного навчання Moodle існують такі типи тестів: а) вибір однієї або кількох відповідей із заданого списку; б) питання закритого типу із додаванням пропущених слів; в) вибір одного із варіантів: «Правильно» чи «Неправильно»; г) розрахунок значень та інші.

Розроблені тестові завдання можна угрупувати у категорії, із яких при автоматичному формуванні тесту $є$ можливість задати випадковий вибір одного, двох чи більше питань. Вибираючи певну категорію тестів відповідно до поставленої дидактичної мети, викладач може утворювати велику кількість різних тестів. Наприклад, для визначення рівня підготовленості до вивчення інформатики, ми обирали із бази завдань нескладні питання. Для проведення оцінювання попереднього рівня засвоєного студентами навчального матеріалу, що розглядатиметься на практичному занятті, ми обирали невелику кількість питань відповідно до теми навчального заняття. Такий контрольний захід відбувається протягом 5-10 хв. на початку заняття та дає змогу викладачу, проаналізувавши результати всієї групи, внести корективи у проведення заняття. При проведенні підсумкового тематичного контролю ми обираємо питання аналітичного рівня, які дають можливість для більш грунтовного оцінювання набутих студентами знань та вмінь.

При розробці тестових завдань можна визначити структуру оцінок (відсоток виконаних правильно), наприклад, як представлено на рисунку $2-1$, та надати текстовий коментар для підтримки зусиль студентів (рис. 2 - 2). 


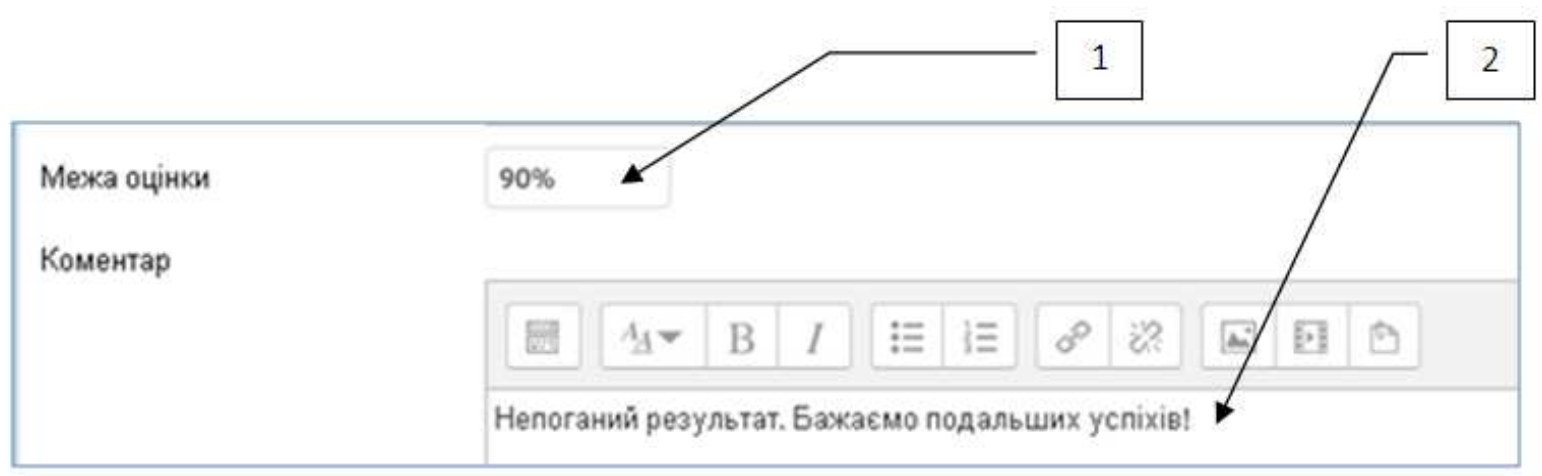

Рис. 2. Розробка тестового завдання

Також при розробці тестових завдань ми могли визначати кількість спроб, які дозволялись студентам для виконання тесту. Така кількість залежала від поставленої нами дидактичної задачі: якщо тест призначався для самоконтролю студентами - кількість спроб не обмежувалось. Є можливість також зробити вибір: краща оцінка, середня тощо.

Тестова технологія оцінювання результатів навчальної діяльності застосовується також і як метод навчання. Для цього ми після проведення контрольних заходів, відкриваємо правильні відповіді до кожного тестового завдання (рис. 3).

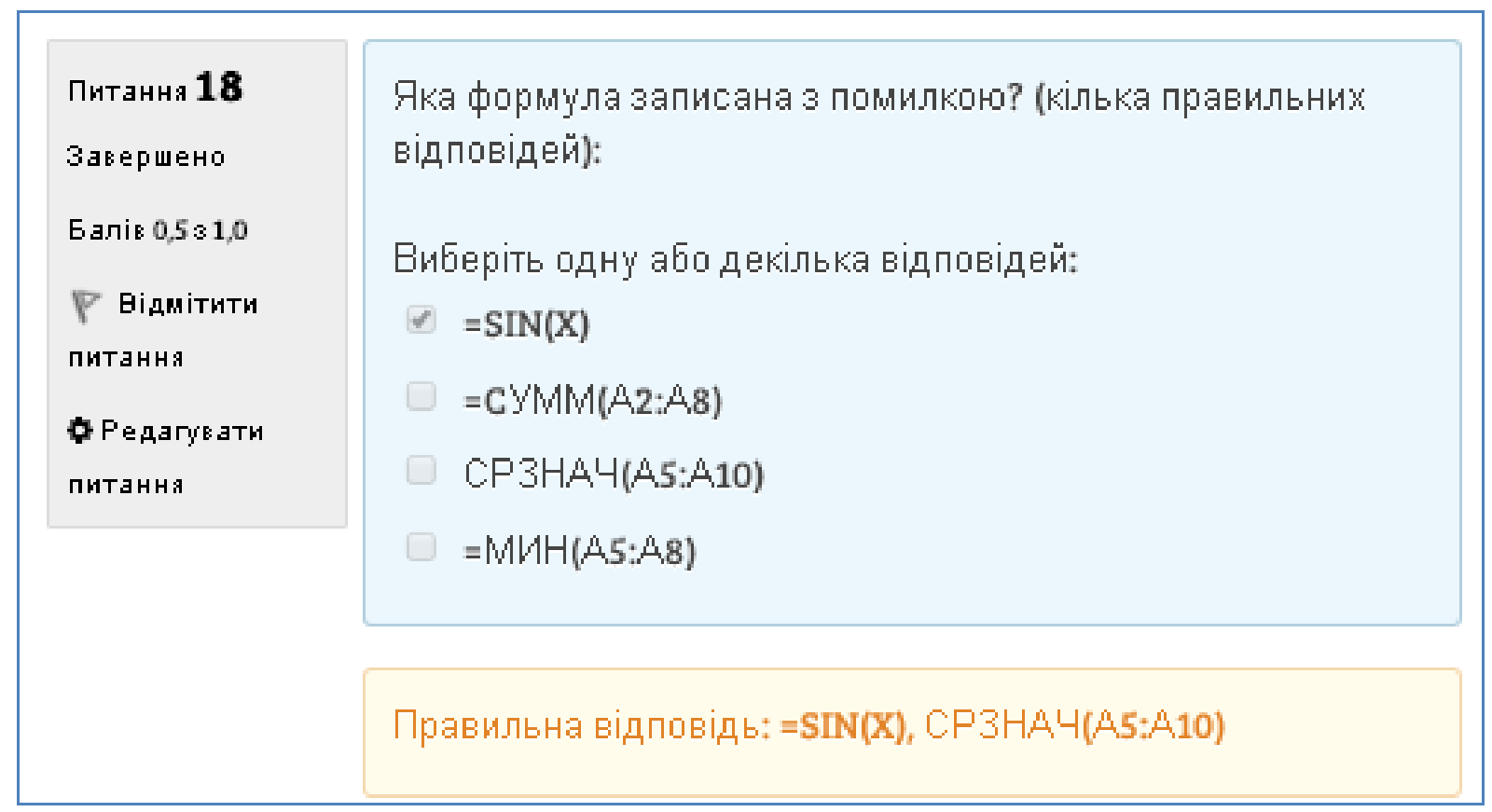

Рис. 3. Самооиінювання результатів тестування

У системі дистанційного навчання Moodle можна створити і інші компоненти, які використовуються у навчальній діяльності: термінологічний тематичний словник, відео- та аудіо матеріали, теоретичний матеріал тощо.

Відкритість і доступність результатів навчальної діяльності для всіх зацікавлених 
осіб (студенти, їх батьки, організатори начального процесу) призводить до нівелювання рівня суб'єктивізму, реалізації постійного моніторингу поточної успішності, сприяє збільшенню мотивації студентів до навчання через відчуття ними справедливості отриманих оцінок. Такі можливості також реалізується через електронні журнали успішності, які розроблені відповідними програмними продуктами та доступні у мережі Інтернет.

Активність студентів у навчальній діяльності, розуміння ними значення набуття широкого діапазону професійно-орієнтованих компетенцій, встановлення власних освітніх цілей призводить до розвитку їх як суб'єктів навчання. Т. Шамова підкреслює, що «суб' єктність студентів - це складна інтегрована характеристика особистості, що визначає активність та самостійність, які виявляються у досвіді студента, що називається суб' єктним» [4, с. 96].

Важливим аспектом для формування студента як суб'єкта навчального процесу $є$ оприлюднення на Web-сайті інформації щодо процедур оцінювання результатів навчальної діяльності (критерії оцінювання для кожного навчального блоку; складові поточної оцінки; робоча програма навчальної дисципліни; порядок проведення поточного та підсумкового оцінювання тощо).

\section{4. ВИСНОВКИ ТА ПЕРСПЕКТИВИ ПОДАЛЬШИХ ДОСЛІДЖЕНЬ}

Вміння аналізувати, високий рівень критичного мислення, широкий кругозір, здатність швидко реагувати та приймати рішення - невід’ємні характеристики фахівця у світі глобальних i динамічних змін. Використання можливостей інформаційнокомунікаційних технологій у навчальному процесі дає змогу студентам брати участь у процесі оцінювання навчальних результатів, що призводить до збільшення їх активності при підготовці до практичних та лекційних занять, формує їх відповідальність за ефективність своєї навчальної діяльності. Подальшими дослідженнями мають бути охоплені питання використання можливостей хмарних, мобільних технологій у навчальному процесі. Важливим $є$ і створення спеціалізованих центрів, де фахівців 3 освітніх вимірювань могли б аналізувати тестові завдання з різних навчальних дисциплін та надавати кваліфіковані консультації розробникам щодо їх удосконалення.

\section{СПИСОК ВИКОРИСТАНИХ ДЖЕРЕЛ}

1. Дибкова Л. М. Інтерактивні інформаційні технології у навчальному процесі сучасного вишу /Л.М.Дибкова// Вища освіта України: теоретичний та науково-методичний часопис. № 2 (додаток 2). - Тематичний випуск «Науково-методичні засади управління якістю освіти у вищих навчальних закладах» - Луцьк: СПД Гадяк Жанна Володимирівна, друкарня «ВолиньПоліграф»тм, 2013. - С. 364371.

2. Контроль та оцінювання навчальних досягнень студентів економічного університету / М. І. Радченко, М. В. Артюшина, Г. М. Романова та ін. - К.: КНЕУ, 2010. - 332 с.

3. Поясок Т. Б. Система застосування інформаційних технологій у професійній підготовці майбутніх економістів у вищих навчальних закладах : автореф. дис ... д-ра пед. наук : 13.00 .04 / Т. Б. Поясок.- К., 2010. -42 c.

4. Шамова Т. И. Управление образовательными системами / Т. И. Шамова, Т. М. Давыденко, Г. Н. Шибанова. - М.: Изд. центр «Академия», 2002. - 384 с. 


\title{
ИНФОРМАЦИОННО-КОММУНИКАЦИОННЫЕ ТЕХНОЛОГИИ В КОНТЕКСТЕ ОЦЕНИВАНИЯ РЕЗУЛЬТАТОВ ОБУЧЕНИЯ СТУДЕНТОВ ВЫСШИХ УЧЕБНЫХ ЗАВЕДЕНИЙ УКРАИНЫ
}

\author{
Дыбкова Людмила Николаевна \\ кандидат педагогических наук, доцент кафедры информатики \\ Государственное высшее учебное заведение «Киевский национальный экономический университет имени \\ Вадима Гетьмана», г. Киев, Украина \\ dybln@meta.ua
}

\begin{abstract}
Аннотация. Статья посвящена оцениванию результатов учебной деятельности студентов с использованием современных информационно-коммуникационных технологий. Автор подчеркивает, что целью современной системы образования является не только приобретение будущими специалистами профессиональных знаний и навыков, но и формирование способности к их постоянному обновлению и модернизации в будущей профессиональной деятельности. Активизации оценочной деятельности студентов также способствует максимальная их информированность о критериях оценивания знаний и умений по каждой дисциплине, а также доступность учебных результатов через электронный журнал, который размещен в сети Интернет. В статье также представлены учебные задачи, основанные на активном оценивании студентами полученных результатов в процессе проведения лекций, практических занятий, самостоятельной работы и тестирования.
\end{abstract}

Ключевые слова: активная оценочная деятельность студентов; информационнокоммуникативные технологии; самостоятельная работа студентов; оценивание учебных результатов; учебное задание.

\section{INFORMATION AND COMMUNICATION TECHNOLOGIES IN THE CONTEXT OF EVALUATION OF THE RESULTS OF TEACHING STUDENTS IN THE UNIVERSITIES OF UKRAINE}

\author{
Liudmyla M. Dybkova \\ PhD (in Pedagogy), associate professor \\ Kyiv National Economic University named after Vadym Hetman, Kyiv, Ukraine \\ dybln@meta.ua
}

\begin{abstract}
The article is devoted to assessing the results of students' training activities using modern information and communication technologies. The author stresses that the aims of current educational system are not only the acquisition of future professional with knowledge and skills, but also the formation of abilities to their constant updates and upgrades in their future professional activity. The article presents the learning tasks, which are based on students' learning activities during the lectures, practical classes, independent work and tests. Activation of students' evaluation activities is also promoted by their maximum awareness about criteria of evaluation the results on each discipline, as well as the availability of educational outcomes for students using electronic register which are accessed from Internet.
\end{abstract}

Keywords: active learning activities; the evaluation of learning outcomes; individual work of students; information and communication technologies; learning task.

\section{REFERENCES (TRANSLATED AND TRANSLITERATED)}

1. Dybkova L. The interactive information technologies in the educational process of modern university/ L. Dybkova // Vyshcha osvita Ukrainy: teoretychnyi ta naukovo-metodychnyi chasopys. № 2 (dodatok 2). - 
Tematychnyi vypusk «Naukovo-metodychni zasady upravlinnia yakistiu osvity u vyshchykh navchalnykh zakladakh»- Lutsk: SPD Hadiak Zhanna Volodymyrivna, drukarnia «VolynPolihraf»TM , 2013. - p. 364-371. (in Ukrainian)

2. The control and evaluation of educational achievements of students of Economic University / M. I. Radchenko, M. V. Artiushyna, H. M. Romanova ta in. - K.: KNEU, 2010. - 332 p. (in Ukrainian)

3. Poiasok T. B. System of information technologies use in professional preparation of future economists in higher educational establishments: avtoref. dys ... d-ra ped. nauk : 13.00.04 / T. B. Poiasok.- K., 2010. - 42 p. (in Ukrainian)

4. Shamova T. I. Management of educational systems / T. I. Shamova, T. M. Davydenko, G. N. Shibanova. M.: Izd. centr «Akademija», 2002. - 384 p. (in Russian)

Conflict of interest. The author has declared no conflict of interest.

\section{(oc) EY-NC-SA}

This work is licensed under Creative Commons Attribution-NonCommercial-ShareAlike 4.0 International License. 